\title{
Manching revisited
}

\section{SUSANNE SIEVERS*}

In 1960 Werner Krämer reported in ANTIQUTTY on excavations at the oppidum of Manching (Krämer 1960), setting out both the leitmotivs in the history of the oppidum and an overview of the finds. After 40 years, the excavated area of the oppidum (380 ha) has grown by more than 20 ha and the picture of Manching has acquired new colours and shadows. The 1996-1999 excavations, in the northwest of the oppidum, with finds from the 2nd century and the first half of the 1st century BC, should be at the centre of any overview (FIGURE 1).

Krämer highlighted the important economic geographical position of Manching, at the point where the Paar flows into the Danube. The convergence of the excavations in 1984-1987 (Maier et al. 1992) and 1996-1999 with an old meander of the Danube, which runs through the oppidum in the north, has now raised the possibility of a Celtic harbour. The most recent investigations (Völkel/Weber in Sievers 2000) show that this meander contained water in Celtic times, with an opening into the Danube, and hence was well suited as a landing place. Hydraulic installations and a concentration of grain stores on the edge of the landing place fit well with these findings.

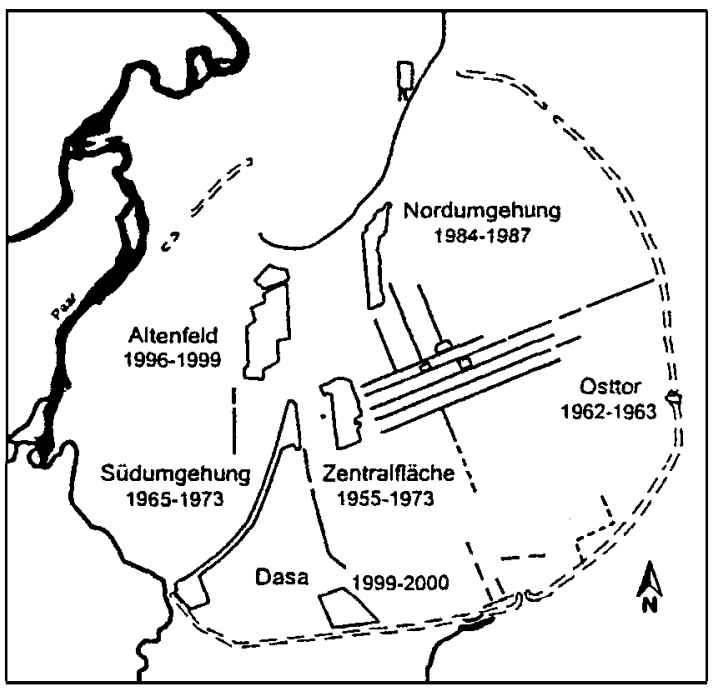

FIGURE 1. Plan showing the 1955-2000 excavation areas.

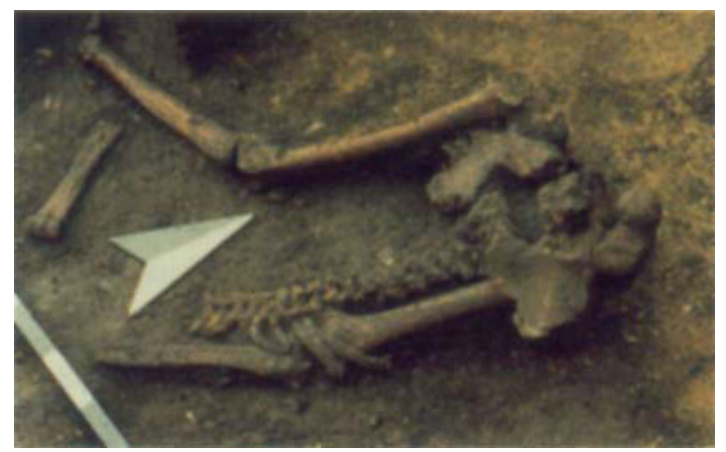

FIGURE 2.

Partial

human

skeleton from

a grave.

(Photo RGK.)

FiguRE 3.

Coin hoard

found in

1999. (Photo

J. Bahlo RGK.)

FIGURE 4.

Waste

products of

bronze

working from

the area of a

Grubenhaus.

(Photo A.

Mittermüller.)
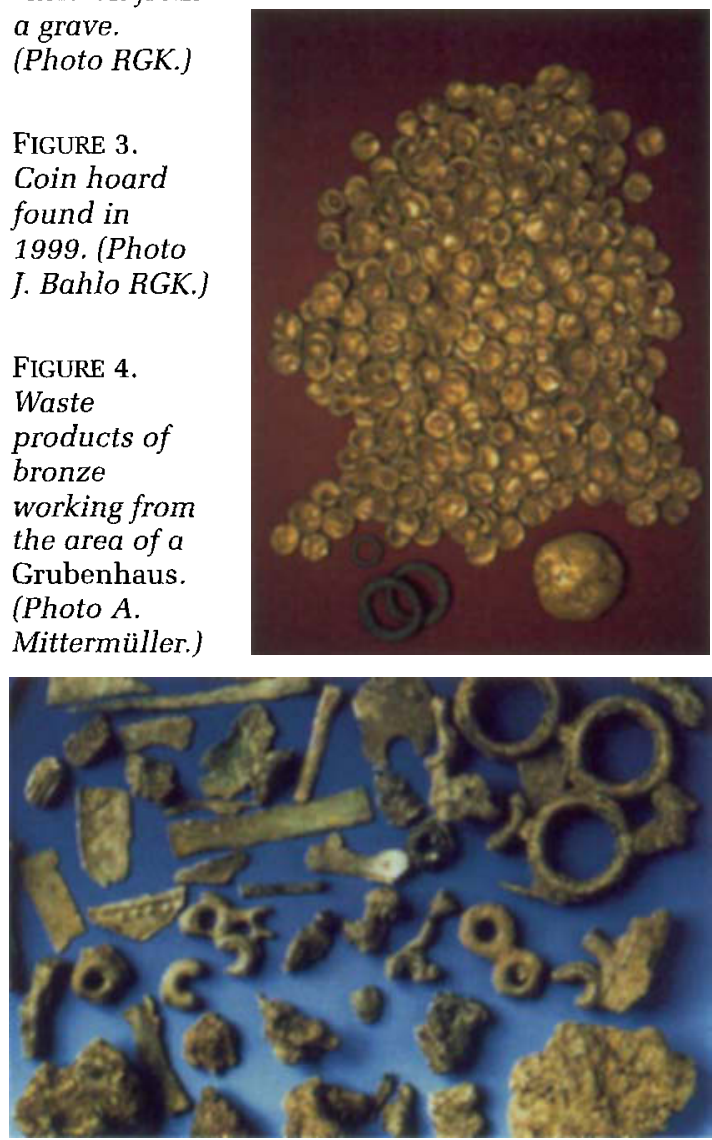

* Römisch-Germanische Kommission des Deutschen Archäologischen Instituts, D-60325 Frankfurt am Main, Palmengartenstraße 10-12, Germany.

ANTIQUITY 76 (2002): $943-4$ 
As well as wood and stones for the construction of the town wall, built around the end of the 2nd century $\mathrm{BC}$, amphoras were unloaded here. These were probably used to transport not only wine but also fish sauces, as attested by a tiny bone from a Mediterranean fish (Manhart in Sievers 1998) which was recovered from a densely populated quarter further south. A concentration of other prestige goods, such as campana and glass dishes, were found here, as well as special weapons such as a dagger, fragments of chain mail or spurs, suggesting the presence of equites. A 62-g lead weight with a divine bust (the second of its kind from Manching (Sievers 2000)) attests to the importance of trade.

Related constructions were laid out along the route of a trackway flanked by trenches. In addition to wells and storage pits, houses, commercial buildings and longhouses, whose function (as stables or magazines) remains unclear, there are unusual types of buildings (quadrangular enclosures with a central structure, Umgangsbau (processional buildings) and hall-like structures) which indicate status or have some cultic significance (Leicht in Sievers 1998). A small bronze hippocampus and a horse's hoof carved from antler horn found near by underscore this impression. The closest parallels for such special structures are found in the 'Viereckschanzen'. On the basis of this, it seems that a member of the élite, active in secular as well as religious spheres, resided in the centre of the area excavated in 19961999. Here, as throughout the excavation area, scattered human skeletal remains were found, which can no longer be associated with the capture of Manching by the Romans, but should rather be interpreted as connected with a multi-tiered burial practice or as trophy skulls (Lange 1983). However, complete and partial skeletons (FIGURE 2) still raise many questions. The lack of late La Tène burials from large parts of southern Germany makes comparison with other regions of the Celtic world difficult. An interesting find in this connection came from between a densely inhabited area and the landing place. Although not a burial, it is reminiscent of élite burials from the central Rhein region because of the associated finds: over a burial trench for a body were found remains which could be interpreted as parts of a cart and bronze vessels. In addition there were the remains of weapons and other equipment. Almost all the finds had traces of burning. However, the lack of human remains hinders interpretation.

Only $10 \mathrm{~m}$ from this find, a coin hoard of 483 staters and a 217-g gold nugget were recovered from a posthole (FIGURE 3), representing a religious deposition or a cache. The hoard is unusual in that it does not contain the typical southern German
'Regenbogenschüsselchen' but rather Bohemian coinage (Ziegaus in Sievers 2000). Overall there is a noticeable concentration of finds indicative of Bohemia from the 1996-1999 excavation area. A sherd inscribed BOIOS, published by Werner Krämer (1982), accords well with this. The most recent work raises doubts whether such finds should be attributed in all cases to trade contacts; a settlement of Bohemian Celts cannot be ruled out at Manching.

To the south of the trackway lies an area devoted to craftsmen. In fact, at Manching evidence of craft facilities is widespread, suggesting that each of the farmsteads, so typical of Manching, may have had its own forge. This area, however, was the first to be identified as exclusively a craft area, with almost no living quarters, characterized by Grubenhäuser. As well as iron and bronze working (FIGURE 4), pottery-making was practised; numerous Tüpfelplatten [lit. spotting plates/boards] also suggest preparatory work for coin production. Because the Celtic horizon does not survive here, individual production processes can only be reconstructed from the materials found. Large quantities of slag and remains of furnaces (air bricks) are generally indicative of metalworking. Additional finds show that large-scale recycling of scrap material, both iron and bronze, took place here. Secondarily, folded pieces of sheet metal, particularly ornamental fittings, which had been discarded, indicate that weapons (scabbards and shield bosses) and cauldrons were dismantled here with the metal being recycled (Leicht \& Sievers 1998). Nowhere else in the oppidum can recycling be attested on this scale. The question of where the scrap metal was obtained remains unanswered, whether there was deliberate collection of defective objects or whether it was plunder.

The new excavations provide new insight into numerous important aspects, such as economy and trade, religion and social structure which allow us to assess the importance of the oppidum. Work on the analyses is expected to continue until 2004.

\section{References}

KRÄMER, W. 1960. The oppidum of Manching, Antiquity 34: 191-9. 1982. Graffiti auf Spätlatènekeramik aus Manching, Germania 60: 489-99.

LANGE, G. 1983. Die menschlichen Skelettreste aus dem Oppidum von Manching. Wiesbaden: Franz Steiner Verlag. Die Ausgrabungen in Manching 7.

LEICHT, M. \& S. StEVERS. 1998. Recycling im Oppidum von Manching? Das Archäologische Jahr in Bayern: 60-62.

MAIER, F. et al. 1992. Ergebnisse der Ausgrabungen 1984-87 in Manching. Wiesbaden: Franz Steiner Verlag. Die Ausgrabungen in Manching 15.

SEVERS, S. et al. 1998. Vorbericht über die Ausgrabungen 19961997 im Oppidum von Manching, Germania 76: 619-72. 2000. Vorbericht über die Ausgrabungen 1998-1999 im Oppidum von Manching, Germania 78: 355-94. 